\title{
In vitro and In vivo Antitumor Activity of Tiliacorinine in Human Cholangiocarcinoma
}

\author{
Somkid Janeklang ${ }^{1,3}$, Archawin Nakaew ${ }^{4}$, Kulthida Vaeteewoottacharn ${ }^{1,3,5}$, \\ Wunchana Seubwai ${ }^{2,3}$, Patcharee Boonsiri ${ }^{1}$, Gorkem Kismali ${ }^{6}$, Apichart \\ Suksamrarn $^{4}$, Seiji Okada ${ }^{5}$, Sopit Wongkham ${ }^{1,3 *}$
}

\begin{abstract}
Cholangiocarcinoma (CCA) is a fatal cancer with poor prognosis and less than $10 \%$ of CCA patients can be offered surgical cure. Conventional chemotherapy results in unfavorable outcomes. At present, plant-derived compounds are gaining interest as potential cancer therapeutics, particularly for treatment-refractory cancers. In this study, antitumor activity of tiliacorinine, the major alkaloid isolated from a tropical plant, on CCA was first demonstrated. Antiproliferative effects of tiliacorinine on human CCA cell lines were investigated using SRB assays. Acridine orange/ethidium bromide staining, flow cytometric analysis and DNA laddering assays were used for apoptotic determination. Apoptosis-related proteins were verified by Western blotting and antitumor activity of tiliacorinine in vivo was demonstrated in CCA xenografted mice. Tiliacorinine significantly inhibited proliferation of human $\mathrm{CCA}$ cell lines with $\mathrm{IC}_{50} 4.5-7 \mu \mathrm{M}$ by inducing apoptosis through caspase activation, upregulation of $\mathrm{BAX}$, and down-regulation of $\mathrm{Bcl}_{\mathrm{xL}}$ and XIAP. Tiliacorinine considerably reduced tumor growth in CCA xenografted mice. These results demonstrated antitumor effects of tiliacorinine on human CCA in vitro and in vivo. Tiliacorinine may be an effective agent for CCA treatment.
\end{abstract}

Keywords: Antitumor activity - apoptosis - growth inhibition - bile duct cancer - alkaloid

Asian Pac J Cancer Prev, 15 (17), 7473-7478

\section{Introduction}

Cholangiocarcinoma (CCA), a malignant cancer arising from bile duct epithelium, is a rare liver cancer but a serious public health problem in the northeast of Thailand as it has the highest incidence and mortality rate in the world (Sripa and Pairojkul, 2008). Generally, only $10 \%$ of patients present with early-stage disease are considered surgical candidates (Han et al., 2005) and chemotherapy is the option left for these inoperable patients (Chou and Talalay, 1984). However, the outcome of the chemo-drug treatment is unfavorable with the five year survival lesser than $10 \%$ (Butthongkomvong et al., 2013; Rizvi and Gores, 2013; Thunyaharn et al., 2013). To reduce the mortality rate of CCA, new effective treatment strategies are needed.

Plant-derived compounds are gaining interest as potential cancer therapeutics (Shukla, 2007; Aras et al., 2014), particularly for treatment-refractory cancers such as CCA (Naus et al., 2007). In this study, tiliacorinine (Figure. 1A), the bisbenzylisoquinoline alkaloid isolated from a tropical medicinal plant, Tiliacora triandra (Colebr.) Diels, was investigated for antitumor activity in CCA cell lines in vitro and in vivo. The molecular mechanism by which tiliacorinine induces apoptosis of CCA was also determined. Our findings suggested tiliacorinine to be a new promising compound for effective treatment against human CCA.

\section{Materials and Methods}

\section{Chemicals and reagents}

Cell culture reagents were purchased from Gibco/ Invitrogen (Carlsbad, CA). Antibodies were obtained from companies as indicated: $\mathrm{Bcl}$-2-associated $\mathrm{X}$ protein $(\mathrm{BAX}), \mathrm{B}$-cell leukemia protein $\mathrm{xL}\left(\mathrm{Bcl}_{\mathrm{xL}}\right), \mathrm{X}$-linked inhibitor of apoptosis protein (XIAP), and poly-adenosine diphosphate ribose polymerase (PARP) from Santa Cruz Biotechnology (Santa Cruz, CA); anti-caspase-3 and-9, goat anti-rabbit IgG- and goat anti-mouse IgG-conjugated to horseradish peroxidase (HRP) from Cell Signaling Technology (Beverly, MA), and $\beta$-actin antibody from

${ }^{1}$ Department of Biochemistry, ${ }^{2}$ Department of Forensic Medicine, ${ }^{3}$ Liver fluke and Cholangiocarcinoma Research Center, Faculty of Medicine, Khon Kaen University, Khon Kaen, ${ }^{4}$ Department of Chemistry and Center of Excellence for Innovation in Chemistry, Faculty of Science, Ramkhamhaeng University, Bangkok, Thailand, ${ }^{5}$ Division of Hematopoiesis, Center of AIDS Research, Kumamoto University, Honjo, Kumamoto, Japan, ${ }^{6}$ Department of Biochemistry, Faculty of Veterinary Medicine, Ankara University, Ankara, Turkey*For correspondence: sopit@kku.ac.th 
Sigma Chemical Co (St Louis, MO).

\section{Cell lines and cell culture}

Four human CCA cell lines-KKU-M055, KKU-100KKU-M213 and KKU-M214-were established from primary tumors of CCA patients as described previously (Sripa et al., 2005; Seubwai et al., 2010). All cells were cultured at $37^{\circ} \mathrm{C}$ with $5 \% \mathrm{CO}_{2}$ in Ham's F-12 containing $1 \%$ antibiotics-antimycotics solution and $10 \%$ FBS.

\section{Isolation of tiliacorinine}

Tiliacorinine was isolated from Tiliacora triandra as described previously (Pachaly and Khosravian, 1988) with modification. Briefly, $10.0 \mathrm{~kg}$ of pulverized dried roots and stems were macerated successively with n-hexane and ethyl acetate to give the hexane $(535.20 \mathrm{~g})$ and ethyl acetate $(519.86 \mathrm{~g})$ extracts. The plant material was then extracted with methanol-chloroform-ammonium hydroxide (15:5:1). After solvent evaporation, glacial acetic acid was added followed by ammonium hydroxide. The insoluble polymeric material was removed from the aqueous suspension and the latter was extracted with chloroform. The crude alkaloid extract was chromatographed to give tiliacorinine $(1.053 \mathrm{~g})$ and a mixture of minor alkaloids $(300 \mathrm{mg})$. More tiliacorinine (96mg) was obtained from the ethyl acetate extract by column chromatographic separation. The spectroscopic (proton and carbon-13 NMR, and mass spectra) data were consistent with the literature values (Wiriyachitra, 1981; Pachaly and Khosravian, 1988). Tiliacorinine was dissolved in DMSO and diluted with completed media to the indicated concentrations.

\section{In vitro cytotoxicity test}

The effects of tiliacorinine on the proliferation of CCA cells were determined using SRB assay (Skehan et al., 1990). Briefly, CCA cells (3,000 cells/well) were incubated with tiliacorinine in a 96-well plate. At indicated time points, cells were treated with $10 \%$ ice-cold trichloroacetic acid and stained with $0.4 \%$ SRB in $1 \%$ acetic acid. The stained proteins were solubilized and the absorbance at 540nm was measured (Vichai and Kirtikara, 2006). Dose-response curves were plotted, and the concentration of drug required to inhibit cell proliferation by $50 \%\left(\mathrm{IC}_{50}\right)$ was calculated using the Calcusyn software (Biosoft, Oxford, UK).

\section{DNA fragmentation assay}

The isolation of fragmented DNA was carried out as previously described (Herrmann et al., 1994). Briefly, $5 \times 10^{5}$ cells were lyzed in $100 \mu \mathrm{L}$ of $10 \mathrm{mM}$ Tris- $\mathrm{HCl}$ buffer (pH 7.4), $10 \mathrm{mM}$ EDTA and 0.5\% Triton X-100. Final samples were dissolved in $40 \mu \mathrm{L}$ of Tris-EDTA buffer, $\mathrm{pH} 8.0$, subjected to agarose gel electrophoresis and stained with ethidium bromide.

\section{Acridine orangelethidium bromide double staining}

Cells $(3,000$ cells $/ 100 \mu \mathrm{L})$ were treated with $0.01 \%$ DMSO or various concentrations of tiliacorinine for $72 \mathrm{~h}$ and subjected to acridine orange/ethidium bromide $(\mathrm{AO} /$ EB) staining as previously described (Petit et al., 1995).
The stained cells were visualized under a fluorescent microscope (Nikon Eclipse TS100, Nikon Corporation, Tokyo, Japan). Multiple photos (9 fields/sample) were taken at randomly-selected areas and apoptotic cells were count using Image ProPlus 7.0 (Media Cybernetics, Inc., Bethesda, MD). A minimum of 100 total cells were count and expressed as a percentage. Tests were done in triplicate.

\section{Western blotting}

Cells were lyzed with RIPA buffer $(50 \mathrm{mM}$ Tris$\mathrm{HCl}, \mathrm{pH} 7.4,150 \mathrm{mM} \mathrm{NaCl}, 1 \% \mathrm{NP}-40$ ) supplemented with cocktail proteinase inhibitors (Roche, Mannheim, Germany). Proteins in cell lysates were separated by a $10 \%$ SDS-polyacrylamide gel electrophoresis according to Laemmli (Laemmli, 1970) and electro-transferred onto a polyvinylidene difluoride membrane according to Bolt and Mahoney (Bolt and Mahoney, 1997). The membrane was blocked with $1 \%(\mathrm{w} / \mathrm{v})$ skim milk, $0.1 \%$ tween $(\mathrm{v} / \mathrm{v})$ in Tris-buffered saline, $\mathrm{pH} 7.4$ for $30 \mathrm{~min}$ and incubated with specific primary antibodies at $4^{\circ} \mathrm{C}$ overnight and secondary antibody conjugated-HRP at room temperature for $2 \mathrm{~h}$. The expression level of proteins were detected using Amersham ECL Plus Western blotting detection reagents (GE Health care, Piscataway, NJ) and captured with ImageQuant ${ }^{\mathrm{TM}} 400$ and analyzed with ImageQuant ${ }^{\mathrm{TM}}$ TL software.

\section{Flow cytometric analysis of apoptotic cells}

Flow cytometric analysis of cell cycle distribution was performed using a FACSCalibur flow cytometer (BD-Biosciences, San Jose, CA) as previously described (Seubwai et al., 2010). Briefly, cells were fixed with $70 \%$ ethanol at $-20^{\circ} \mathrm{C}$ overnight and stained with $10 \mu \mathrm{g} / \mathrm{mL}$ propidium iodine (PI; Sigma, St Louis, MO) in phosphate buffer saline for $30 \mathrm{~min}$ in the dark. A total of 10,000 cells were analyzed by flow cytometry. Sub-G1 peak was analyzed using BD FACSDiva software (BD Biosciences, San Jose, CA).

\section{In vivo assay}

Bulb/c Rag-2 Jak3 double knock-out mice (Ono et al., 2011) aged 8-10 week old were housed and monitored in the animal research facility according to the institutional guidelines. All experimental protocols were approved by the Institutional Animal Care and Use Committee, Kumamoto University (Kumamoto, Japan). Mice were subcutaneously injected with $4 \times 10^{6}$ of KKU-M213 cells at both flank sides. Three days after CCA cell-injection, mice were intraperitoneally injected with $0.01 \%$ DMSO (control group; $\mathrm{n}=5)$ or tiliacorinine $(10 \mathrm{mg} / \mathrm{kg}$ body weight; $n=5$ ) once daily for 3 consecutive days. Body weights and tumor volumes were measured every 3 days. Tumors were removed and weighed 9 days after inoculation.

\section{Statistical analysis}

Experimental data were analyzed using SPSS 16.0 Windows Evaluation software (SPSS Inc., Chicago, IL). The results are presented as the mean \pm standard deviation of at least 3 separated experiments. Statistical significance 
was determined with the Student $\mathrm{t}$ test. $\mathrm{p}$ values $<0.05$ were considered significant.

\section{Results}

Tiliacorinine inhibits growth of human CCA cells

In order to determine the growth inhibitory effect of tiliacorinine on human CCA cells-KKU-M055, KKU-100, KKU-M213, and KKU-M214-cells were treated with various concentrations of tiliacorinine for $72 \mathrm{~h}$ and investigated by SRB assay. Growth inhibitory effects of tiliacorinine on the tested cells were KKUM055>KKU-M213>KKU-M214>KKU-100 with $\mathrm{IC}_{50}$ values of $4.5 \pm 0.3,5.7 \pm 0.2,6.1 \pm 0.3$, and $7.0 \pm 0.6$ respectively (Figure 1B). Treated cells exhibited dosedependent sensitivity to tiliacorinine from 1.7-8.7 $\mu \mathrm{M}$. As KKU-M214 and KKU-100 were less sensitive to tiliacorinine, they were selected as representative of CCA cells for the subsequent studies.

Tiliacorinine suppresses growth of human CCA cells by inducing apoptosis

We further investigated whether tiliacorinine inhibited growth of human CCA cells by induction of apoptosis. Apoptotic indices were determined by 3 different approaches. AO/EB double staining was applied to discriminate the live, apoptotic and necrotic cells. Exposure of KKU-M214 and KKU-100 cells to 4-7 $\mu \mathrm{M}$ of tiliacorinine significantly induced apoptotic cells with typical apoptotic features e.g., cell shrinkage, membrane

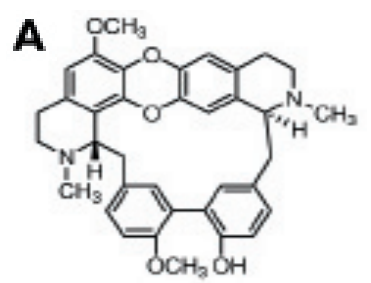

Tiliacorinine (TC)

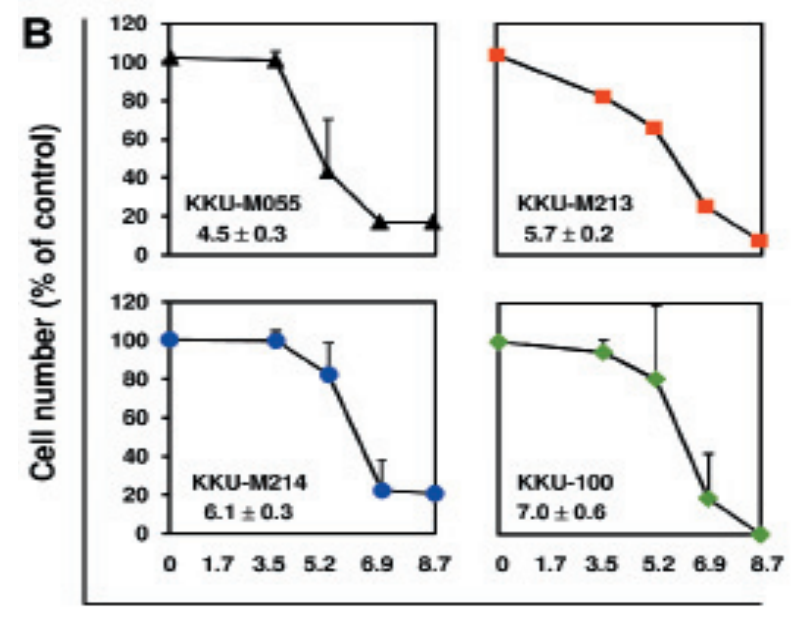

Concentration ( $\mu \mathrm{M})$

Figure 1. Chemical Structure and Antiproliferative Effect of Tiliacorinine. (A) The chemical structure of tiliacorinine $\left(\mathrm{C}_{36} \mathrm{H}_{36} \mathrm{~N}_{2} \mathrm{O}_{5}\right)$ with molecular weight of 576.26.(B) Tiliacorinine suppressed proliferation of CCA cell lines. Cells were treated with the indicated concentrations of tiliacorinine for $72 \mathrm{~h}$. The numbers indicate $\mathrm{IC}_{50}$ of tiliacorinine blebbing, and chromatin condensation (Figure 2A; left panel) in a dose-dependent manner (Figure 2A; right panel). Number of dead cells stimulated by tiliacorinine was next validated using flow cytometric analysis with PI staining. Cells treated with tiliacorinine for 48-72h exhibited $45-60 \%$ apoptotic cells in the sub G1 peaks which were significantly higher than the controls $(\mathrm{p}<0.05$; Figure 2B). Degradation of nuclear DNA, the hallmark of apoptotic cells, was determined by DNA fragmentation assay. Cells treated with various concentrations of tiliacorinine for 24,48 , and $72 \mathrm{~h}$ showed a gradual increase of DNA ladders, in both dose-and time-dependent manners (Figure 2C).

Tiliacorinine induces apoptosis through caspase activation

To determine whether tiliacorinine induced apoptosis via caspase activation, $\mathrm{KKU}-\mathrm{M} 214$ was treated with $\mathrm{IC}_{50}$ $(6 \mu \mathrm{M})$ of tiliacorinine for 24,48 , and $72 \mathrm{~h}$ and whole cell
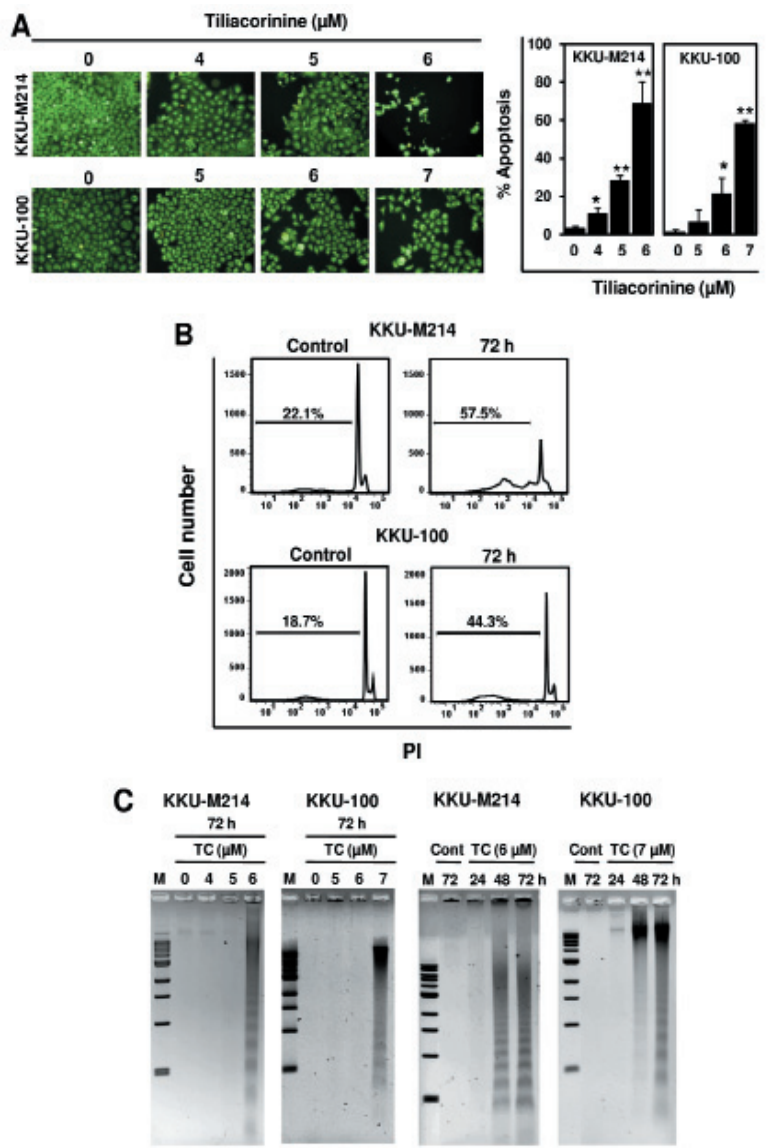

Figure 2. Tiliacorinine Induced Apoptosis in Human CCA Cells. (A) Left panel: Apoptotic cells were determined using orange/ethidium bromide staining. KKU-M214 and KKU-100 cells were treated with $0.01 \%$ DMSO or tiliacorinine at the indicated concentrations for $72 \mathrm{~h}$. Cells were captured at 200x magnification; right panel: apoptotic cells expressed as a percentage from each treatment were compared. Results are mean $\pm \mathrm{SE}$ and $* \mathrm{p}<0.05, * * \mathrm{p}<0.01$. (B) The degree of apoptosis induced by tiliacorinine was quantified by a flow cytometry with PI staining. Sub-G1 DNA content represented the fractions undergone apoptotic DNA degradation, was evaluated. (C) DNA fragmentations of tiliacorinine treated cells were shown as time and dose dependent manners. $\mathrm{M}=1 \mathrm{~Kb}$ DNA ladder marker. The figures are representative results of three independent experiments 


\section{Somkid Janeklang et al}

lysates were subjected to western blotting. Tiliacorinine activated caspase-3, -9 and PARP cleavages in a timedependent fashion (Figure 3A). In addition, tiliacorinine significantly increased expression of a proapoptotic protein, BAX, and decreased expression of antiapoptotic proteins, XIAP and $\mathrm{Bcl}_{\mathrm{xL}}$, in a time-dependent manner (Figure 3B).

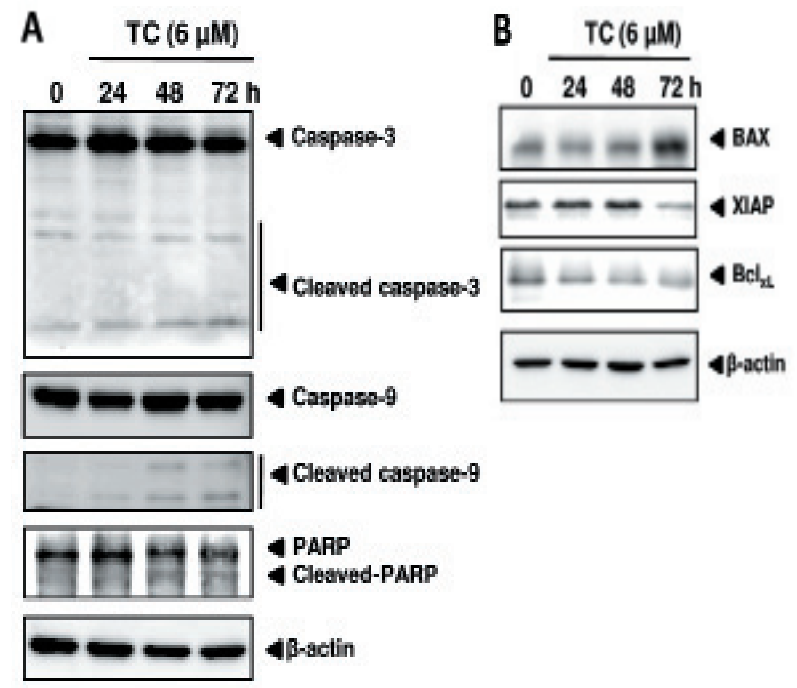

Figure 3. Tiliacorinine Induced Apoptosis Via Caspase Activation. Western blot analysis of tiliacorinine treated KKU-M214 cells at indicated time points were determined. $\beta$-actin was used as an internal control. (A) Expression of proteins in the caspase related pathway; (B) Proapoptotic and antiapoptotic proteins. $\mathrm{TC}=$ tiliacorinine
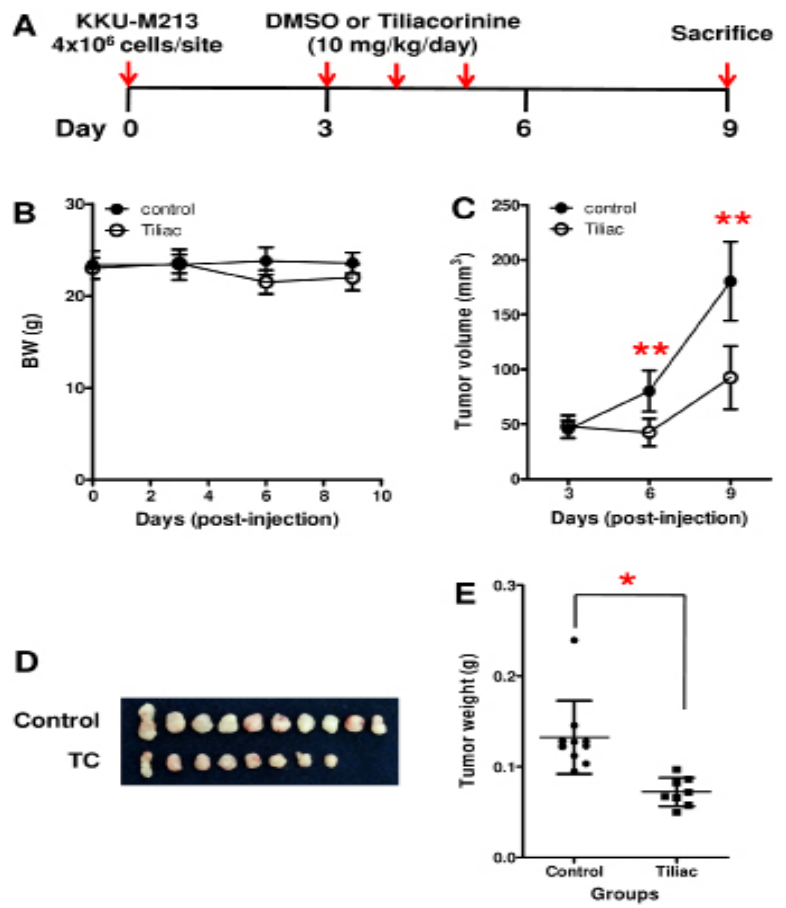

Figure 4. Antitumor Activity of Tiliacorinine in CCA Xenografted Mice. (A) Treatment protocol. Mice were subcutaneously injected with KKU-M213 in both flanks and intraperitoneally injected with DMSO or tiliacorinine once daily for 3 consecutive days (red arrows). (B) Average body weights and $(\mathbf{C})$ tumor volumes of mice in each group were evaluated. (D) Tumor tissues and (E) tumor weights from DMSO and tiliacorinine-treated mice were compared. ${ }^{*} \mathrm{p}<0.05,{ }^{*} \mathrm{p}<0.001$

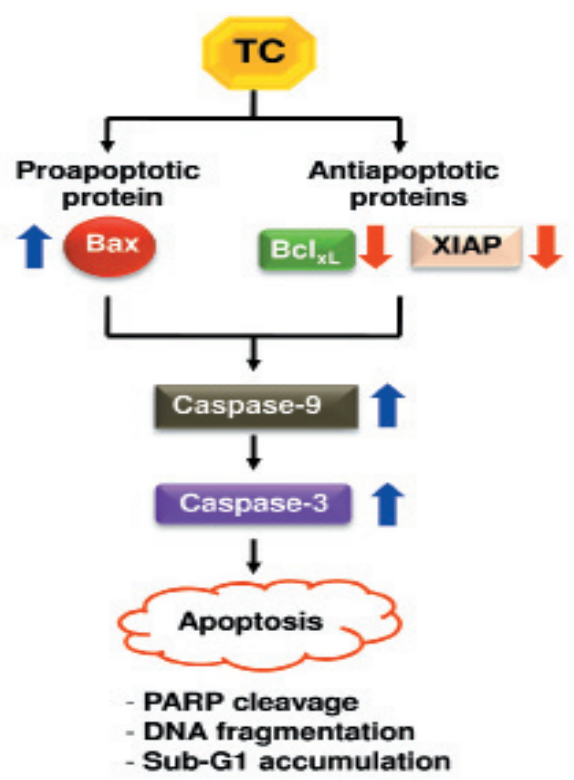

Figure 5. Proposed Mechanism of Tiliacorinine on Apoptotic Induction in Human CCA Cells

Tiliacorinine reduced tumor growth in CCA xenografted mice

To investigate the antitumor activity of tiliacorinine in animal model, KKU-M213 cells were subcutaneously injected into both flanks of mice and tiliacorinine or DMSO (control group) was intraperitoneally injected once daily for 3 consecutive days, 3 days post-CCA cell-injection (Figure 4A). Body weights of mice from both groups were not significantly different (Figure 4B). One mouse in tiliacorinine treated group died on day 8 and hence all mice were sacrificed on day 9 . Mean tumor volumes from tiliacorinine treated group $\left(45.16 \pm 12.52 \mathrm{~mm}^{3}\right)$ was significantly lower than those of the control group $\left(80.22 \pm 18.75 \mathrm{~mm}^{3}\right)$ instantly on day 3 of treatment (Figure. $4 \mathrm{C} ; \mathrm{p}<0.001$ ). On day 9 , mean tumor weights from tiliacorinine treated group $(0.07 \pm 0.02 \mathrm{~g})$ was significantly lower than those of the control group $(0.13 \pm 0.04 \mathrm{~g})$ (Figure 4E; $\mathrm{p}<0.05)$.

\section{Discussion}

Tiliacorinine, the major alkaloid isolated from the medicinal plant-Tiliacora triandra has been proved for anti-malarial activity (Dechatiwongse et al., 1987) and antimycobacterial activity (Sureram et al., 2012). In this study, the anticancer activity of tiliacorinine was first demonstrated in vitro and in vivo. Tiliacorinine effectively inhibited proliferation of CCA cells via induction of apoptosis and significantly reduced tumor growth in CCA xenografted mice model. These results indicate the therapeutic potential of tiliacorinine against human CCA.

Tiliacorinine inhibited growth of four human CCA cell lines with $\mathrm{IC}_{50}$ ranging from 4.5-7.0 $\mu \mathrm{M}$. Comparing to other natural compounds, tiliacorinine seems to be more potent than tannic acid and sesquiterpene but less effective when compared to caged xanthones. Tannic acid, a natural polyphenolic compound, inhibited proliferation of malignant human cholangiocytes with $\mathrm{IC}_{50}$ of 60 $\mu \mathrm{M}$ (Marienfeld et al., 2003) while sesquiterpene-the 
derivative of zerumbone-showed antiproliferative activity against KKU-100 cell line with an $\mathrm{IC}_{50}$ of $16.44 \mu \mathrm{M}$ (Songsiang et al., 2010). The growth inhibitory effect of four caged xanthones-isomorellin, isomorellinol, forbesione and gambogic acid-on KKU-100 showed $\mathrm{IC}_{50}$ ranging from 0.11-2.64 $\mu \mathrm{M}$ (Hahnvajanawong et al., 2010).

Tiliacorinine exhibited antiproliferative activity on CCA cell lines as time-and dose-dependent manners, with a narrow range of $4.0-7.5 \mu \mathrm{M}$ at $72 \mathrm{~h}$. Comparing to other CCA cell lines, KKU-100 was the less sensitive cell line toward most of conventional chemotherapeutic agent tested (Tepsiri et al., 2005). KKU-100 exhibited the $\mathrm{IC}_{50}$ of 5-fluorouracil, mitomycin-C, paclitaxel and cisplatin $=1,018 \mu \mathrm{M}, 45 \mu \mathrm{M}, 39 \mu \mathrm{M}$ and $37 \mu \mathrm{M}$, respectively. KKU-100, however, was sensitive to tiliacorinine with the $\mathrm{IC}_{50}$ of $7 \mu \mathrm{M}$ which was similar to other CCA cell lines. This highlights tiliacorinine as a potent agent for CCA treatment.

Tiliacorinine inhibited CCA cell growth by inducing apoptosis as evidenced by the results from three different assays. First, tiliacorinine treatment increased number of apoptotic cells as determined by AO/EB staining. Second, DNA ladder, the hallmark of apoptosis revealed by DNA fragmentation assay was clearly demonstrated in cells treated with tiliacorinine. Third, tiliacorinine treated cells significantly increased apoptotic cells in sub G1 peak as demonstrated by flow cytometry. Induction of apoptosis has been considered to be the major mechanism of anticancer drug discovery (Reed, 2001).

The molecular mechanism by which tiliacorinine induced apoptosis was shown to be via activation of caspase-3, -9, and consequently PARP cleavage. Tiliacorinine also up-regulated BAX, a proapoptotic protein, and down-regulated XIAP and $\mathrm{Bcl}_{\mathrm{xL}}$ in human CCA cells. Induction of apoptosis via caspase-activation pathways seems to be the general mechanisms of anticancer agents from natural compounds, such as cepharanthine, a biscoclaurine alkaloid from roots of Stephania cepharantha Hayata (Wu et al., 2001; Seubwai et al., 2010), emodin, an anthraquinone derivative (Yaoxian et al., 2013) and berberine, an isoquinoline alkaloid (Yip and Ho, 2013).

Several attempts have been made to find new agents that effectively inhibited growth and metastatsis of CCA, however, most of them demostrated the effects in vitro, e.g., diethyldithiocarbamate (Srikoon et al., 2013), histone deacetylase inhibitors (Sriraksa and Limpaiboon, 2013). The antitumor activity of tiliacorinine was obviously demonstrated in CCA cell lines and CCA xenografted mice. Tumor volumes and tumor weights of tiliacorinine treated group were 2 folds reduced compared to the control group. Tiliacorinine appeared to have a rapid antitumor activity as it was administrated only 3 consecutive days after CCA cell-injection and the tumor volume was significantly reduced instantly. As this study was the first report on the antitumor activity of tiliacorinine in the xenografted mouse model, the pharmaco-kinetic, drug safety and efficacy of tiliacorinine have to be investigated cautiously.

The abundance of literature suggests that defects along apoptotic pathways play a crucial role in carcinogenesis and that many new treatment strategies targeting apoptosis are feasible for the treatment of various cancers (Wong, 2011; Sankari et al., 2012). Additionally, almost clinically used anticancer drugs are aimed to activate apoptosis of tumor cells (Hadi et al., 2000). In this study, tiliacorinine showed apoptotic effect on human CCA cells and suppressed tumor growth in CCA xenografted mice, suggesting this auspicious alkaloid an effective agent for CCA treatment. Nevertheless, further intensive study in safety and efficacy of tiliacorinine is highly recommended. Furthermore, to overcome cancer by achieving synergistic therapeutic effect, reducing toxicity, and minimizing the drug resistance (Chou, 2010), further study on drug combination between tiliacorinine and the conventional chemotherapeutic drugs is encouraged.

\section{Acknowledgements}

This study was supported by Research grants from Khon Kaen University and the Higher Education Research Promotion and National Research University Project of Thailand, Office of the Higher Education Commission, through the Health cluster (SHeP-GMS) to S. Wongkham. S. Janeklang is supported by the Royal Golden Jubilee-Commission on Higher Education PhD Program (PHD/0133/2550). A. Suksamrarn and A. Nakaew acknowledge supports from The Thailand Research Fund and Center of Excellence for Innovation in Chemistry. We would like to thank Prof. James A. Will for the English presentation of this manuscript via the Faculty of Medicine Publication Clinic, and the Research Instrument Center, Khon Kaen University, for the service support of flow cytometer.

\section{References}

Aras A, Khokhar AR, Qureshi MZ, et al (2014). Targeting cancer with nano-bullets: curcumin, EGCG, resveratrol and quercetin on flying carpets. Asian Pac J Cancer Prev, 15, 3865-71.

Bolt MW, Mahoney PA (1997). High-efficiency blotting of proteins of diverse sizes following sodium dodecyl sulfatepolyacrylamide gel electrophoresis. Anal Biochem, 247, 185-92.

Butthongkomvong K, Sirachainan E, Jhankumpha S, et al (2013). Treatment outcome of palliative chemotherapy in inoperable cholangiocarcinoma in Thailand. Asian Pac J Cancer Prev, 14, 3565-8.

Chou TC (2010). Drug combination studies and their synergy quantification using the chou-talalay method. Cancer Res, 70, 440-6.

Chou TC, Talalay P (1984). Quantitative analysis of dose-effect relationships: the combined effects of multiple drugs or enzyme inhibitors. Adv Enzyme Regul, 22, 27-55.

Dechatiwongse T, Chavalittumrong P, Nutakul W (1987). Isolation of the in vitro antimalarial principles from tiliacora triandra diels. bull. Dept. Med Sci, 29, 6 .

Hadi SM, Asad SF, Singh S, et al (2000). Putative mechanism for anticancer and apoptosis-inducing properties of plantderived polyphenolic compounds. IUBMB Life, 50, 167-71.

Hahnvajanawong C, Boonyanugomol W, Nasomyon T, et al (2010). Apoptotic activity of caged xanthones from Garcinia hanburyi in cholangiocarcinoma cell lines. World 
J Gastroenterol, 16, 2235-43.

Han SL, Zhu GB, Yao JG, et al (2005). Diagnosis and surgical treatment of primary hepatic cholangiocarcinoma. Hepatogastroenterology, 52, 348-51.

Herrmann M, Lorenz HM, Voll R, et al (1994). A rapid and simple method for the isolation of apoptotic DNA fragments. Nucleic Acids Res, 22, 5506-7.

Laemmli UK (1970). Cleavage of structural proteins during the assembly of the head of bacteriophage T4. Nature, 227, 680-5.

Marienfeld C, Tadlock L, Yamagiwa Y, et al (2003). Inhibition of cholangiocarcinoma growth by tannic acid. Hepatology, 37, 1097-104.

Naus PJ, Henson R, Bleeker G, et al (2007). Tannic acid synergizes the cytotoxicity of chemotherapeutic drugs in human cholangiocarcinoma by modulating drug efflux pathways. J Hepatol, 46, 222-9.

Ono A, Hattori S, Kariya R, et al (2011). Comparative study of human hematopoietic cell engraftment into BALB/c and C57BL/6 strain of rag-2/jak3 double-deficient mice. $J$ Biomed Biotechnol, 2011, 539748.

Pachaly P, Khosravian H (1988). New bisbenzylisoquinoline alkaloids from Tiliacora triandra. Planta Med, 54, 433-7.

Petit PX, Lecoeur H, Zorn E, et al (1995). Alterations in mitochondrial structure and function are early events of dexamethasone-induced thymocyte apoptosis. J Cell Biol, 130, 157-67.

Reed JC (2001). Apoptosis-regulating proteins as targets for drug discovery. Trends Mol Med, 7, 314-9.

Rizvi S, Gores GJ (2013). Pathogenesis, diagnosis, and management of cholangiocarcinoma. Gastroenterology, 145, 1215-29.

Sankari SL, Masthan KM, Babu NA, et al (2012). Apoptosis in cancer - an update. Asian Pac J Cancer Prev, 13, 4873-8.

Seubwai W, Vaeteewoottacharn K, Hiyoshi M, et al (2010). Cepharanthine exerts antitumor activity on cholangiocarcinoma by inhibiting NF-kappaB. Cancer Sci, 101, 1590-5.

Shukla Y (2007). Tea and cancer chemoprevention: a comprehensive review. Asian Pac J Cancer Prev, 8, 155-66.

Skehan P, Storeng R, Scudiero D, et al (1990). New colorimetric cytotoxicity assay for anticancer-drug screening. $J$ Natl Cancer Inst, 82, 1107-12.

Songsiang U, Pitchuanchom S, Boonyarat C, et al (2010). Cytotoxicity against cholangiocarcinoma cell lines of zerumbone derivatives. Eur J Med Chem, 45, 3794-802.

Srikoon P, Kariya R, Kudo E, et al (2013). Diethyldithiocarbamate suppresses an NF-kappaB dependent metastatic pathway in cholangiocarcinoma cells. Asian Pac J Cancer Prev, 14, 4441-6.

Sripa B, Leungwattanawanit S, Nitta T, et al (2005). Establishment and characterization of an opisthorchiasisassociated cholangiocarcinoma cell line (KKU-100). World J Gastroenterol, 11, 3392-7.

Sripa B, Pairojkul C (2008). Cholangiocarcinoma: lessons from Thailand. Curr Opin Gastroenterol, 24, 349-56.

Sriraksa R, Limpaiboon T (2013). Histone deacetylases and their inhibitors as potential therapeutic drugs for cholangiocarcinoma - cell line findings. Asian Pac J Cancer Prev, 14, 2503-8.

Sureram S, Senadeera SP, Hongmanee P, et al (2012). Antimycobacterial activity of bisbenzylisoquinoline alkaloids from tiliacora triandra against multidrug-resistant isolates of mycobacterium tuberculosis. Bioorg Med Chem Lett, 22, 2902-5.

Tepsiri N, Chaturat L, Sripa B, et al (2005). Drug sensitivity and drug resistance profiles of human intrahepatic cholangiocarcinoma cell lines. World J Gastroenterol, 11, 2748-53.

Thunyaharn N, Promthet S, Wiangnon S, et al (2013). Survival of cholangiocarcinoma patients in northeastern Thailand after supportive treatment. Asian Pac J Cancer Prev, 14, 7029-32.

Vichai V, Kirtikara K (2006). Sulforhodamine B colorimetric assay for cytotoxicity screening. Nat Protoc, 1, 1112-6.

Wiriyachitra PP, B (1981). Alkaloids of Tiliacora triandra. Aust. J Chem, 34, 2001-4.

Wong RS (2011). Apoptosis in cancer: from pathogenesis to treatment. J Exp Clin Cancer Res, 30, 87.

Wu J, Suzuki H, Zhou YW, et al (2001). Cepharanthine activates caspases and induces apoptosis in jurkat and K562 human leukemia cell lines. J Cell Biochem, 82, 200-14.

Yaoxian W, Hui Y, Yunyan Z, et al (2013). Emodin induces apoptosis of human cervical cancer hela cells via intrinsic mitochondrial and extrinsic death receptor pathway. Cancer Cell Int 13,71 .

Yip NK, Ho WS (2013). Berberine induces apoptosis via the mitochondrial pathway in liver cancer cells. Oncol Rep, 30, 1107-12. 